\title{
REGAINING THE ECONOMIC EDGE: POLICY PROPOSALS FOR HIGH-SKILL WORKER AND STUDENT AUTHORIZATIONS
}

\author{
Jeff Papa and Jessica Whelan*
}

The unrivaled dominance of the United States' economic power and institutions of higher education, coupled with its need to compete for hearts and minds in third-world countries during the Cold War, led to the development of a U.S. immigration system which focused more on family unification, refugee protection, protection of U.S. labor markets, and diversity than on the need to compete economically with other nations. This framework can be seen in both the rules surrounding foreign students attending U.S. universities and in rules regarding permanent residence and short term visas for highly skilled foreign workers.

A recent report by the National Foundation for American Policy found that foreign students comprise "70 percent of the full-time graduate students (masters and PhDs) in electrical engineering, 63 percent in computer science, 60 percent in industrial engineering, and more than 50 percent in economics, chemical engineering, materials engineering and mechanical engineering." ${ }^{1}$ Given this alarming statistic that the majority of critical science, technology, engineering, and mathematics (STEM) graduate students are foreign visitors, how will the critical occupations requiring these skills in the United States be filled? More specifically, setting aside for purposes of this paper the larger issue of the need to grow U.S. student interest in STEM fields, how can the short-term STEM needs of the United States be met? Beyond this domestic concern, is the current balance of education simply working to train foreign students to compete with the United States after they return home?

In this paper we will examine the current state of noteworthy U.S. practices in higher education, short term professional visas, and permanent residence. After this analysis of current U.S. practices, we will offer several practical suggestions for reforming U.S. laws in these areas.

\footnotetext{
* Jeff Papa is the Chief of Staff and Chief Legal Counsel of the Indiana State Senate. He practiced in the field of immigration law for seven years at Barnes and Thornburg, LLP in Indianapolis, Indiana. Jessica Whelan is a former law clerk to then-Chief Justice of the Indiana Supreme Court Brent Dickson and is currently an attorney at Bingham Greenebaum Doll LLP in Indianapolis, Indiana.

${ }^{1}$ Stewart Anderson, The Importance of International Students to America, NAT'L Found. FOR AM. POL'Y (2013), available at http://www.nfap.com/pdf/New\%20NFAP\%20Policy \%20Brief\%20The\%20Importance\%20of\%20International\%20Students\%20to\%20America, \%20July\%202013.pdf.
} 


\section{METHODOLOGY}

Our intent with this article is not to offer an academic study or analysis of visa and other issues but rather to take a pragmatic approach and offer practical solutions to the problems faced by immigrants, their families, and those who work with these individuals in the visa process.

We began our research by conducting several interviews with individuals who work with foreign students at Indiana colleges and universities as well as practitioners in the field of immigration law. These interviews helped us identify the everyday issues faced by these individuals. We then set out to determine how these issues could be addressed within the current U.S. immigration framework. While the system is not perfect, and likely never will be, it is our hope that this article will spur meaningful debate in this country on how to improve the efficiency and effectiveness of our immigration system.

\section{FOREIGN STUDENTS}

In discussing policy changes to the current U.S. immigration system, it is important to first have a general understanding of the various classifications for immigrants. It is also important to understand the terminology used in the field of immigration law. In common parlance, the term "visa" is often used to describe the authorization for a foreign individual to be present or work in the United States. ${ }^{2}$ This usage is incorrect. On the contrary, a visa is the entry document needed to enter the United States at a port of entry, while "status" describes the underlying permission to be in or work in the United States. ${ }^{3}$ Foreign students wishing to come to the United States to study have several options at their disposal depending on the length of their stay and their course of study.

The $\mathrm{F}$ visa is the visa required for students attending university, college, high school, private elementary school, seminary, conservatory, or another academic institution, including a language training program. ${ }^{4}$ Students with F-1 status must maintain a full course of study, defined for college and university students as twelve credit hours or more and must possess non-immigrant intent; that is, they must intend to return to their home country upon completion of their course of study. ${ }^{5}$ Family members with F-2 status may accompany the F-1 student, but those family members

\footnotetext{
2 Jeff Papa, Basic Options in the Non-Immigrant Business Context, 15 IND. INT’L \& CoMP. L. REV. 279, 280 (2005).

${ }^{3}$ Id.

${ }^{4}$ Student Visa, U.S. Department of State Bureau of Consumer AfFairs, (last visited July 31, 2013) http://ravel.state.gov/content/visas/english/study-exchange/studentt.htm 1 [hereinafter Student Visas]; 8 C.F.R. § 214.2(f) (2013).

5 C.F.R. $\S \S 214.2(f)(1)(\mathrm{i})(\mathrm{f})(6)(\mathrm{B})(2013) ;$ Id.
} 
may not work or attend school. ${ }^{6}$

The $\mathrm{M}$ visa is the visa required for students attending a short-term vocational or recognized nonacademic institution other than a language training program. ${ }^{7} \mathrm{M}-1$ status is valid for the length of the student's program, plus up to six months of practical training following the program. This time period, however, may not exceed one year. ${ }^{8} \mathrm{M}-2$ family members may accompany the M-1 student, but like F-2 family members, they may not work or attend school. ${ }^{9}$

The $\mathrm{J}$ visa is a non-immigrant visa issued to exchange visitors participating in programs that promote cultural exchange. $\mathrm{J}$ status related issues, and proposed suggestions are discussed more fully below.

\section{A. Attracting Foreign Students and Improving Their Experience}

\section{Allow F-2 Status-Holders to Work and/or Study}

A common theme that arose during our interviews was the inability of F-2 status-holders, particularly spouses of F-1 status-holders, to work or study while on F-2 status. Although this policy may have made good sense in the past when spouses accompanying F-1 status-holders primarily constituted wives following their student husbands (when, at the time, women traditionally did not work outside the home or attend school), this policy is now outdated and should be reviewed if the United States wishes to attract and retain top talent. While this prohibition on work likely stems from formerly protectionist policies of the United States enacted during the Cold War era, such policies are no longer relevant in modern times where often both spouses work and/or study.

A policy change in this area would increase U.S. competitiveness in attracting top foreign students who may otherwise choose to study elsewhere. Because F-1 status-holders are typically in the United States for four years or longer, the F-2 work and school restrictions place unnecessary burdens on family members who often must make the choice to come to the United States with F-1 status-holders, or remain in their home countries to work or attend school. Allowing F-2 family members to work or attend school in the United States would facilitate cultural assimilation for family members who often feel isolated during their time in the United States. Increased assimilation of family members could have a positive effect on the number of quality F-1 students who decide to stay in the United States and seek permanent employment after completion of their studies.

\footnotetext{
6 8 C.F.R. § 214.2(f)(15)(i)(ii) (2013).

${ }^{7}$ Student Visas, supra note 6; 8 CFR 214.2(m) (2013).

8 C.F.R. § 214.2(m)(5) (2013).

9 8 C.F.R. § 214.2(m)(17) (2013).
} 
Since M-1 students are limited to one year of residency, a policy change allowing M-2 family members to work and attend school is not as imperative as allowing F-2 family members to work or attend school. However, it may be worth considering whether allowing M-2 family members limited authorization to work or attend school would also have a positive effect on the caliber of students attracted to the United States for vocational or other nonacademic training.

\section{Increase Flexibility in Foreign Students' Study}

Many of the individuals we spoke with in international offices at Indiana colleges and universities expressed frustration on behalf of their international students at the rigidity the law imposes on the courses of study for international students.

For example, the law restricts the number of online credit hours that foreign students may take each semester. F-1 and J-1 students are restricted to a maximum of three online credit hours per semester. ${ }^{10} \mathrm{M}-1$ students, by contrast, are not permitted to take any online courses during their course of study. ${ }^{11}$ These restrictions have become outdated as technology continues to improve and online coursework becomes more prevalent.

In a 2011 Pew Research Center survey, seventy-seven percent of college presidents reported that their institutions offer online courses. ${ }^{12}$ Eighty-nine percent of four-year public colleges and universities and sixty percent of four-year private schools offer online classes. ${ }^{13}$ Forty-six percent of college graduates surveyed who had graduated in the past ten years reported that they had taken an online course, and the trend is expected to continue. ${ }^{14}$ By limiting foreign students' ability to take online courses like the rest of their American classmates, we are restricting foreign students' options and providing a disincentive for the best and brightest to study in the United States, particularly those students interested in pursuing degrees in technology-related fields.

Potential changes in policy could range anywhere from eliminating the restrictions on online courses ${ }^{15}$ to an overall increase in the number of

108 C.F.R. § 241.2(f)(6)(i)(G) (2013).

118 C.F.R. $\S 241.2(\mathrm{~m})(9)(\mathrm{v})$ (2013) ("No on-line or distance education classes may be considered to count toward an M-1 student's full course of study requirement if such classes do not require the student's physical attendance for classes, examination or other purposes integral to completion of the class.”).

${ }^{12}$ Kim Parker, Amanda Lenhart \& Kathleen Moore, The Digital Revolution and Higher Education (Aug. 28, 2011) http://www.pewsocialtrends.org/2011/08/28/the-digital-revolution-and-highereducation/.

${ }^{13} \mathrm{Id}$.

${ }^{14} I d$.

15 This option is unlikely and is not recommended given the potential for abuse. For example, foreign students could use a fully-online program as a back door to obtain 
credit hours permitted to be completed online (e.g., fifty percent of credit hours each semester). A more tailored approach depending on the foreign student's course of study is yet another option. In this more tailored approach, students involved in courses of study that lend themselves to online learning (e.g., computer programming, information technology, engineering) would be permitted to complete more credits through online courses than students in other programs. This tailored approach would have the benefit of allowing students for whom it is practical, if not necessary, to increase the number of online credit hours taken, while at the same time maintaining integrity in the system by ensuring that only the students who would benefit from the increase can take advantage of it.

\section{Remove Barriers to Practical Training}

Students with F-1 status have the option of working in the United States by engaging in practical training during or after their programs of study. Curricular Practical Training (CPT) is work performed during a student's course of study that is "an integral part of an established curriculum." 16 Optional Practical Training (OPT) is work "directly related to the [student's] major area of study," performed during school vacations or breaks, or while school is in session, ${ }^{17}$ and upon completion of a student's course of study. ${ }^{18}$

Rigidity in the CPT/OPT requirements is another common complaint among professionals who work with F-1 students. First, the requirement that the work performed by the student be "an integral part of an established curriculum" for CPT, and "directly related to the student's major area of study," is unnecessarily strict and overly vague. Second, students are limited to twelve months of practical training through any combination of CPT and OPT. ${ }^{19}$ Thus, if a student participates in two six-month internships under CPT authorization during a four-year course of study, the student is ineligible for any OPT upon completion of his or her course of study. Likewise, if a student works on vacations and breaks under OPT authorization, and such work totals twelve months, the student is ineligible for any post-completion OPT. Rigidity in practical training requirements is confusing and frustrating to students and may serve to discourage the best and brightest students in other countries from attending American programs.

residency in the United States. Additionally, a fully-online program would not necessitate the foreign student to maintain residency in the United States while participating in the program.

${ }^{16} 8$ C.F.R. § 214.2(f)(10)(i) (2013).

${ }^{17}$ OPT performed while school is in session may not exceed twenty hours per week. 8

C.F.R. § 214.2(f)(10)(ii)(A)2).

18 C.F.R. § 214.2(f)(10)(i) (2013).

198 C.F.R. $\S 214.2(10)$ (2013). 
Policy changes in the administration of CPT/OPT programs should be considered to encourage and reward students seeking practical training. Employers and an increasing number of colleges and universities place high value on internships, externships, or other types of practical training; ${ }^{20}$ so students should be granted flexibility in the relatedness of their training to their program of study. ${ }^{21}$

To facilitate this, the relatedness requirement should be clarified to give greater guidance to university officials approving CPT opportunities. Additionally, CPT performed for credit as part of a student's program of study should not be counted against a student's quota of twelve-months of practical training. CPT experience, particularly if done for academic credit, should be seen as an integral part of the student's program of study, and students should not be prevented from gaining further experience at the end of their program of study. Along those same lines, OPT performed during the school term and/or vacations and breaks should not be counted against a student's twelve-month allotment. In essence, a student should be granted the assurance that he or she will be permitted to remain in the United States for twelve months post-completion, regardless of the CPT/OPT performed during the program of study. This would afford foreign students and their families predictability in planning their stay in the United States.

It would also grant recent graduates additional time within which to plan and apply for more permanent status, as well as allow U.S. employers the ability to "try out" recent graduates in jobs prior to sponsoring them for H-1B authorization. Further, if a recent F-1 student graduate has found fulltime employment and an employer willing to sponsor his or her employment, but is not granted $\mathrm{H}-1 \mathrm{~B}$ authorization in the year immediately following completion of his or her program of study due to H-1B quota issues, the graduate would have another opportunity in the following year to apply for H-1B authorization before his or her F-1 OPT work authorization expired. ${ }^{22}$

In sum, both the relatedness requirement of practical training and the duration restrictions on practical training should be relaxed. The United States should also consider adopting two separate practical training limits for F-1 students: a defined period of CPT/OPT during a student's program of study (perhaps nine to twelve months), and twelve months of OPT upon completion of the student's program of study. One common method by which graduates with degrees in certain specialty fields may qualify to remain in the United States and work in their field of specialization is

${ }^{20}$ Allie Grasgreen, Interns Without (Major) Borders (Aug. 8, 2012), http://www.insidehighered .com/news/2012/08/08/more-colleges-pushing-internships-liberal-arts.

${ }^{21}$ Brian Burnsed, Degrees Are Great, but Internships Make a Difference, U.S. News and World Report (Apr. 15, 2010), http://www.usnews.com/education/articles/2010/04/15/when-a-degree-isntenough.

22 See infra Section III. 
utilization of the H-1B classification for a limited number of years as a nonimmigrant worker. ${ }^{23}$ In order to qualify for $\mathrm{H}-1 \mathrm{~B}$ status, the proffered job must typically be one which normally requires a specific bachelor's degree or is so complex and specialized that the ability to perform those duties is normally associated with a particular bachelor's degree (or higher). ${ }^{24}$

\section{B. Retaining Foreign Students in the United States}

\section{Retaining J Status-Holders}

$\mathrm{J}$ status allows nonimmigrant visitors to remain in the United States, generally for no more than eighteen months ${ }^{25}$ in order to undertake a scholarly, trainee, intern, student, specialist, physician, or other similar experience in a field of study for which they are academically and experientially prepared. ${ }^{26}$ Upon successfully completing a $\mathrm{J}$ status experience, an individual typically has extensive academic preparation, significant practical experience, and time spent working or studying within the United States. Often, then, these individuals are potentially very valuable to a U.S. company, university, or government agency which may find great value in retaining the services of this person for the short or long term (and conversely not be pleased about the prospect of the individual going to their home country to compete).

However, often these individuals are subject to the J status two-year home residency requirement. ${ }^{27}$ The U.S. State Department maintains an Exchange Visitors Skills List; foreign nations that appear on the State Department's list may select skills from this list which they believe are critical to the development of their country. ${ }^{28}$ If their field of expertise is selected, $\mathrm{J}$ status nonimmigrants from these countries are subject to this requirement and must return home for at least two years. ${ }^{29}$

The concept for $\mathrm{J}$ status arose during the Cold War as part of the Fulbright-Hays Act of $1961 .^{30}$ This act had as its purposes the establishment and expansion of cultural and educational exchanges to

23 Immigration and Nationality (McCarran) Act § 101, 8 U.S.C. § 1101(a)(15)(H)(i)(b) (2014).

${ }^{24}$ Id.

${ }^{25}$ See 22 C.F.R. § 62.22 (b)(2) (2010).

${ }^{26}$ See 22 C.F.R. § 62.20 (2006) (professors and research scholars); 22 C.F.R. § 62.22 (2010) (trainees and interns); 22 C.F.R. § 62.23 (2008) (college and university students); 22 C.F.R. $\S 62.26$ (2002) (specialists); 22 C.F.R. § 62.27 (2002) (alien physicians).

${ }^{27}$ See 22 C.F.R. § 41.63 (2007).

${ }^{28}$ Exchange Visitor Skills List - 2009, U.S. DePARTMENT OF STATE - BUREAU OF CONSUlaR AFFAIRS, http://travel.state.gov/content/visas/english/study-exchange/exchange/exchange-visitorskills-list.html (last visited Aug. 29, 2014).

${ }^{29}$ See 22 C.F.R. § 41.63 (2007).

${ }^{30}$ Fulbright-Hays Act of 1961, Pub. L. No. 87-256, 75 Stat. 527. 
strengthen ties between nations and assist in the development of friendly countries. $^{31}$ The $\mathrm{J}$ status program, and the two-year home residency requirement, made great sense in 1961 as the United States was the unrivaled economic superpower that was locked in a global struggle for hearts and minds in developing nations. ${ }^{32}$ However, in today's hypercompetitive global economy, the two-year home residency requirement may be an unnecessary impediment to the United States' ability to compete for talent. A good approach here may be to either eliminate the two-year home residency requirement based on the skills list altogether, or to significantly reduce the types of skills (or nationalities) to which it may apply.

The two-year home residency requirement may also be invoked if the program in which the foreign national is participating was funded by either the home country or U.S. government. ${ }^{33}$ If funded by the home government, this requirement is simply fair in order to allow the home government to reap the benefit of funding the student's program. If funded by the U.S. government, this requirement should be eliminated in most cases; it simply prevents the United States from taking advantage of a skill it has paid to develop.

\section{Retaining STEM graduates}

The United States Immigrations and Customs Enforcement General Summary Quarterly Review, issued July 2014, reports that there are currently 1,015,178 F-1 \& M-1 students and 188,382 J-1 exchange visitors currently in the United States. ${ }^{34}$ This makes the United States the leading host country for international students, enrolling approximately one-fifth of all mobile students worldwide as of $2009 .{ }^{35}$ The United States is also the top destination country for foreign students pursuing degrees in the STEM fields. ${ }^{36}$ Yet global competition for top talent, particularly in the STEM fields, makes it imperative for the United States to continue to attract the best and brightest foreign talent, to improve their experience during their studies, and to ultimately retain them to staff the future. ${ }^{37}$

${ }^{31} I d$.

32 Paul B. Stephan, International Governance And American Democracy, 1 Chi. J. Int'l L. 237, 239 (2000).

${ }^{33}$ See 22 C.F.R. $\S 41.63$ (2007).

34 SEVIS By the Numbers, U.S. ImMigrations \& Customs ENFORCEMENT (Apr. 2014), http://www.ice.gov/doclib/sevis/pdf/by-the-numbers.pdf.

${ }^{35}$ Rahul Choudaha \& Li Change, Trends in International Student Mobility, WoRLD EDUCATIONAL SERVICES (Feb. 2012), http://www.wes.org/ras/TrendsInInternationalStudentMobility.pdf.

36 Ruth Ellen Wasem, Immigration of Foreign Nationals with Science, Technology, Engineering, and Mathematics (STEM) Degrees, CONGRESSIONAL RESEARCH SERVICE (Nov. 26, 2012), at 1, http://www.fas.org/sgp/crs/misc/R42530.pdf.

${ }^{37}$ See Position Statement: U.S. Talent Crisis, NAT'L Ass'N OF C.S \& EMP’RS (Oct. 2007), http://www.naceweb.org/advocacy/position-statements/united-states-talent-crisis.aspx. 
One major issue in the current immigration system is the disparity between the number of U.S. students pursuing STEM degrees and the projected need for top talent in STEM careers. ${ }^{38}$ Between 2010 and 2020, employment in STEM occupations is expected to expand faster than employment in non-STEM occupations by seventeen versus fourteen percent. ${ }^{39}$ Further, both government officials and private industry cite "concerns regarding shortages of skilled workers . . compounded by the pending retirements of many baby boomers." 40 Correspondingly, the supply of STEM talent is not keeping up with demand.

Although the number of students receiving degrees from four-year institutions has increased in the United States over the past several decades, the share of students graduating with STEM degrees has declined. The percentage of bachelor's degrees awarded in STEM fields declined from twenty-four percent in 1985 to eighteen percent in 2009. ${ }^{41}$ During the same time period, the percentage of master's degrees awarded in STEM fields dropped from eighteen percent to fourteen percent. ${ }^{42}$ Although the share of doctorate degrees in the STEM fields was relatively stable between 1985 and 2009, the share of those degrees going to domestic students dropped from seventy-four percent to fifty-four percent. ${ }^{43}$ Overall, the number of full-time foreign graduate students in science, engineering, and health fields grew from 91,150 in 1990 to 148,923 in $2009 .{ }^{44}$ In sum, there is an increase in the demand for STEM professionals, a decrease in the share of students pursuing STEM degrees, and of the students pursuing STEM degrees, a decrease in the share of domestic students pursuing such degrees. Policy changes must be made to address this growing issue.

One reason often cited for the shortage of domestic STEM professionals is the lack of a strong foundation in math and science from elementary and secondary school. ${ }^{45}$ The quality of math and science

${ }^{38} I d$.

39 STAFF OF J. ECON. COMM. CHAIRMAN, STEM EdUCATION: PREPARING FOR JOBS OF THE FUTURE 2 (Apr. 2012), available at_http://www.jec.senate.gov/public/index.cfm?a=Files.Serve\&File_id= 6aaa7e1f-9586-47be-82e7-326f47658320.

${ }^{40}$ Id. at 3; See also The Reauthorization of the America Competes Act Before the H. Comm on Sci. Tech., 111th Cong. (2010) (statement of Thomas J. Donohue, CEO, U.S. Chamber of Commerce), available at https://www.uschamber.com/sites/default/files/legacy/testimony/ 100119_americacompetes.pdf; The STEM Workforce Challenge: The Role of the Public Workforce System in a National Solution for a Competitive Science, Technology, Engineering, and Math Workforce, U.S. DEP'T OF LABOR, EMP'T \& TRAINING ADMIN. (Apr. 2007), available at http://doleta.gov/youth_services/pdf/STEM_Report_4\%2007.pdf.

${ }^{41}$ STAFF OF J. ECON. COMM. CHAIRMAN, supra note 37, at 4.

${ }^{42} I d$.

${ }^{43} I d$.

${ }^{44}$ See Wasem, supra note 34, at 3.

45 See STEM Education: Bolstering Future American Competitiveness, COUNCIL OF STATE Gov'TS (2008), http://csg.org/knowledgecenter/docs/TIA_STEM\%20education.pdf. See also CSTA National Secondary Computer Science Survey: Comparison of Results from 2005, 2007, 2009, 
teaching is the greatest factor in improving student achievement in STEM fields, yet not enough K-12 math and science teachers have an educational background or in-field experience in STEM. ${ }^{46}$

Creative solutions are necessary to address future shortages in the STEM fields. One potential solution gaining traction in recent years has been the proposal to create a separate "STEM visa," or an expedited path to legal permanent resident status for those in STEM fields. While the STEM visa idea has gained interest in Congress, efforts to pass the initiative have been unsuccessful as of yet. ${ }^{47}$

Another possibility, which may address several of the issues discussed above, is a new visa category for STEM graduates that would provide an expedited path to legal permanent resident status contingent upon a certain number of years of service teaching K-12 math, science, or technology. Such a program, modeled off of the Teach for America program, in which recent college graduates dedicate at least two years to teaching in low-income communities, ${ }^{48}$ would have the benefit of retaining foreign STEM graduates in the United States, integrating them into the local community and providing highly trained math, science, and technology teachers in our K-12 institutions. These professionals would not count toward H-1B quotas, which are already stretched thin, but rather would be considered in a class of their own. Upon completion of their teaching commitment, these professionals would be given a grace period within which to locate full-time employ in the STEM fields, or could continue on in the teaching profession.

\section{FOREIGN WORKERS}

\section{A. H1-B Quotas}

One of the primary status classifications available to alien professionals with specialized knowledge is the H-1B classification. While the possible permutations of availability and restriction of $\mathrm{H}-1 \mathrm{~B}$ are highly complex, in general, qualification for $\mathrm{H}-1 \mathrm{~B}$ requires that the proffered job is one for which a bachelor's degree or equivalent is the minimum requirement for entry and that the proposed individual who will fill this

2011, and 2013 Surveys, COMPUTER SCI. TCHRS Assoc., http://csta.acm.org/ Research/sub/Projects/ResearchFiles/CSTASurvey2013Comp.pdf (last visited Jan. 23, 2015).

${ }^{46}$ Staff of J. ECON. Comm. Chairman, supra note 37, at 4. See also Table 1-8: Preparation of Public School Mathematics and Science Teachers for Teaching in Their Field, by School Level and Teaching Field: Academic Years 2003-04 and 2007-08, NAT'L SCI. Found., www.nsf.gov/statistics/seind12/c1/tt01-08.htm (last visited Jan.23, 2015).

${ }^{47}$ Wasem, supra note 34 , at 16.

48 “Our Mission,” Teach for America, available at https://www.teachforamerica.org/ourmission (last visited Feb. 21, 2015). 
position possesses the minimum educational requirements. ${ }^{49}$

The number of workers who can attain H-1B classification is limited to an annual quota of 65,000 participants. ${ }^{50}$ This numerical limit does not apply to participants approved for H-1B status to work for institutions of higher learning or related non-profit entities, to those working for a nonprofit or government research organization, or to persons who have earned a master's degree or higher from a U.S. institution of higher learning (although this last exception is capped at 20,000 participants per year). ${ }^{51}$ With allowed renewals, the $\mathrm{H}-1 \mathrm{~B}$ classification may generally be used for a maximum of six years. ${ }^{52}$

The entire annual quota for $\mathrm{H}-1 \mathrm{~B}$ is often subscribed within the first few days of filing. For the FY2014 H-1B availability, the Citizenship and Immigration Service received 124,000 applications within the first week for the 65,000 regular slots and 20,000 advanced degree slots, and had to conduct a lottery among those applicants. ${ }^{53}$ For FY2015 availability, the CIS again received more petitions with the first week than allowed by the entire annual quota and was required to conduct a lottery as to which of those applications would be accepted. ${ }^{54}$

While H-4 status (dependents of H1-B status holders) does not count against the annual H1-B quota, $\mathrm{H}-4$ dependents are not authorized to work in the United States. ${ }^{55}$ This restriction is often a source of great frustration, as those individuals qualified to hold $\mathrm{H}-1 \mathrm{~B}$ status are often married to persons who also possess professional qualifications. The Citizenship and Immigration Service currently is processing a proposed rule which would allow certain $\mathrm{H}-4$ status holders to apply for work authorization. ${ }^{56}$ If the rule becomes effective, it would apply to $\mathrm{H}-4$ spouses (not children) in certain cases where an immigrant petition has been approved, or the principal H1-B has been extended beyond six years based on progress toward permanent residence. ${ }^{57}$

49 Immigration and Nationality (McCarran) Act $\S 101,8$ U.S.C. $\S 1101(a)(15)(H)(i)(b)$ (2014).

${ }^{50}$ See Id. § 1184(g)(1)(A)(vii).

${ }^{51}$ See Id. § 1184(g)(5).

52 See Id. § 1184(g)(4).

53 Press Release, U.S. Citizenship \& Immigr. Serv., USCIS Reaches FY 2014 H-1B Cap (Apr. 8, 2013), available at http://www.uscis.gov/news/uscis-reaches-fy-2014-h-1b-cap.

54 Press Release, U.S. Citizenship \& Immigr. Serv., USCIS Reaches FY 2015 H-1B Cap (Apr. 7, 2014), available at http://www.uscis.gov/news/uscis-reaches-fy-2015-h-1b-cap.

558 U.S.C. § 1184(g)(2).

${ }^{56}$ H-4 Employment Authorization for Certain H-4 Dependent Spouses, 79 Fed. Reg. 26886 (proposed May 12, 2014) (to be codified at 8 C.F.R. pts. 214 and 274a).

${ }^{57}$ Id. 


\section{B. H1-B and Entrepreneurs}

According to U.S. Census Bureau data, "[a]bout three quarters of all U.S. business firms have no payroll. Most are self-employed persons operating unincorporated businesses . . ."58 While in this initial stage, these businesses "account for only about 3.4 percent of business receipts." 59 Additionally, many (if not most) of these businesses fail. ${ }^{60}$

However, further review of census bureau data reveals that the average receipts for these nonemployer entities is around $\$ 45,344 .{ }^{61}$ By comparison, the median income for a nonfamily male householder in 2012 was $\$ 36,989 .{ }^{62}$ A recent review by Forbes Magazine found the number of these nonemployer firms generating more than one million dollars in revenue to be greatly increasing. ${ }^{63}$ More importantly, these businesses are often innovative operations or new applications of technology and may either grow into large employers, or be strategic purchases for existing companies.

In order to petition for H1-B status, the petitioning company must be a U.S. employer. ${ }^{64}$ Where the potential employee is the majority owner and cannot be fired by the petitioning company, the required employeremployee relationship does not exist and H1-B cannot be granted. ${ }^{65}$ While self-petitioning could be subject to heightened fraud potential, the inability to do so likely eliminates many entrepreneurial activities in innovative and creative endeavors (which then likely end up being developed overseas). Perhaps self-petition applications for $\mathrm{H}-1 \mathrm{~B}$ could be allowed with the development of special additional qualifying criteria, along with additional reporting and audit procedures. In many cases, similar barriers and potential solutions exist regarding permanent residence. For example, the labor certification process requires that qualifying employment must be full-time, permanent, and not self-employment. ${ }^{66}$

58 Employment Size of Firms, Employers and Nonemployers, U.S. CENSUS BUREAU, http://www.census.gov/econ/smallbus.html (last visited Jan. 23, 2014).

${ }^{59} \mathrm{Id}$.

60 Moya K. Mason, Research on Small Business, MoYAK.COM, http://www.moyak.com/ papers/small-business-statistics.html (last visited Jan. 23, 2014).

612012 Nonemployer Statistics, U.S. CENSUS BUREAU, http://censtats.census.gov/cgibin/nonemployer/nonsect.pl (last visited July 12, 2014). Average receipts calculated by dividing receipts for all sectors $(\$ 1,030,932,886,000)$ by the number of employers $(22,735,915)$. $I d$.

${ }^{62} \mathrm{Id}$.

63 Elaine Pofeldt, The Rise of the Million Dollar, One-Person Business, ForBEs (June 29, 2013, 6:10 PM), http://www.forbes.com/sites/elainepofeldt/2013/06/29/the-rise-of-themillion-dollar-one-person-business/.

648 C.F.R. § 214.2(h)(2)(i)(A) (2013).

${ }^{65}$ Memorandum from Donald Neufeld, Assoc. Dir., U.S. Citizenship \& Immigration Serv.s Ctr. Operations to Serv. Ctr. Dir.s (Jan. 8, 2010) (on file with author).

6620 C.F.R. § 656.3 (2009). 


\section{Domestic Visa Processing}

As pointed out earlier in this article, status and visa are two distinct concepts. Status is the authorization to undertake a certain type of activity in the United States, for a certain duration of time, while a visa is the document which allows entry into the United States to undertake this status. One can be granted a new status or renewal of a prior status and undertake or continue if already present in the United States, but for any new entries to the United States, most nationalities and status types would also require a visa based upon that status.

As noted in detail in an earlier article, ${ }^{67}$ this means that an employee with a new or renewed status may be allowed to stay in the United States based on that status, but if he or she anticipates any travel out of the United States, he or she must first travel to a U.S. consulate in their home country, Canada, or Mexico simply for the purpose of obtaining a visa stamp for future travel. ${ }^{68}$ Prior to the terrorist attack on September 11, 2001, persons renewing a visa in the same classification could obtain a renewed stamp by mail; ${ }^{69}$ however, this option has been eliminated due to concerns that it did not involve in-person verification of identity. ${ }^{70}$

Requiring professional workers (and their families), who are legally authorized to be in the United States, to travel out of the United States and attend a visa appointment at a U.S. consulate abroad is a massive waste of time, energy, money, and lost work time to U.S. business. A domestic visa processing post (or multiple posts) should be created to handle these visa interviews for those who are already in the United States legally and have already been granted a new or extended status by the immigration service.

This processing center could be established in an economically blighted area (or areas). Rather than sending these legal employees and their families abroad to spend money at foreign hotels, restaurants, taxis, and on foreign airlines, those funds could all be spent right here in the United States, as well as supporting employment of U.S. citizens and permanent residents at the processing facility. These would be in-person interviews, addressing the security concerns which caused the elimination of the bymail renewal system.

This system would reduce lost work-days to U.S. business, and immediately shift a very large amount of money being spent abroad to

\footnotetext{
67 Jeff Papa, Basic Options in the Non-Immigrant Business Context, 15 IND. INT'L \& ComP. L. REV. 279, 295 (2005).

${ }^{68}$ Papa, supra note 4, at 295. For example, to schedule a visa appointment in Canada, one must first visit an official website. OfFicial Visa SERVICES OF THE UNITED STATES OF AMERICA - CANADA, https://usvisa-info.com/en-ca/selfservice/ss_country_welcome (last visited Jan. 23, 2015).

69 U.S. Dept. of State, 9, Foreign AfF. Manual 41.102(2014).

${ }^{70}$ Discontinuation of Reissuance of Certain Nonimmigrant Visas in the United States, 69 Fed. Reg. 35,121 (June 23, 2004).
} 
domestic spending and job creation. Those few individuals examined who may be found out of status or ineligible for some reason could be removed directly from this facility to a third country (and the cost of this could be built into the visa processing fees), or for minor paperwork questions, individuals could be rescheduled for a later date (rather than under the current system, being stuck outside the United States and unable to perform their duties). This proposal was discussed in greater detail in a prior article by this author, but remains a great opportunity for simplification and economic growth. ${ }^{71}$

\section{CONCLUSIONS}

The purpose of this article is to survey professionals in higher education and immigration practitioners to review areas where the current administration of authorized immigration contains inefficiencies, unnecessary, or unintended restrictions, or where Cold War policies remain in place and inhibit U.S. economic competitive abilities unnecessarily. The intent of this paper is not to propose radical change or fundamentally alter the number or types of authorized statuses.

However, when considering the current U.S. crisis in STEM scholarship, the vastly improved economic competitiveness of the rest of the world, and simple bureaucratic prohibitions that exist accidently, or as remnants of old systems, there are several modest changes that can be made to improve U.S. economic competitiveness and efficiency. We have suggested several of these ideas for further discussion. There are many other similar ideas, but these steps could be taken as practical solutions within the currently authorized immigration system without being caught up in the massive undertaking or political aspects of recent debate regarding comprehensive immigration reform and border security.

Regardless of opinions on these broader issues, those activities currently allowed under U.S. law, and discussed in this article, are not perfect and could benefit from modest proposals for change. Hopefully, this article can play a small part in catalyzing discussions which can help move the U.S. economy and education system forward. Our global competition continues to improve in their ability and sophistication; the United States must find new ways to compete in order to retain and regain our economic advantage.

${ }^{71}$ Papa, supra note 4, at 297, 298. 